\title{
EXTENDED TECHNOLOGY ACCEPTANCE MODEL (TAM) FOR ADOPTION OF INFORMATION AND COMMUNICATIONS TECHNOLOGY (ICT) IN THE US CONSTRUCTION INDUSTRY
}

\author{
SUBMITTED: March 2020 \\ REVISED: January 2021 \\ PUBLISHED: May 2021 \\ EDITOR: Esther Obonyo \\ DOI: $10.36680 /$ j.itcon.2021.013 \\ James Sorce, Assistant Professor, \\ University of North Florida \\ Raja R.A. Issa, Professor, \\ University of Florida \\ raymond-issa@ufl.edu
}

The publication of this paper in ITcon journal has been made under special circumstances, to recognise the primary author of the paper who recently passed away. The colleagues and family of the primary author have asked for the paper to be published to help form part of the legacy of his life, as this was to be his first research publication. ITcon journal is sympathetic to this request, and while the paper did not complete the full second review, it has been modified to the extent possible without the first author's input. ITcon journal therefore presents this paper as a recognition of the first accomplishment of the primary author in the publication of academic research.

SUMMARY: The global economic impact of the construction industry cannot be overstated. The use of information and communications technology (ICT) offers a potential for massive cost savings and increases in productivity. Unfortunately, the US construction industry lags behind most other US industries in the implementation of ICT. This research sets out to understand what factors improve the use and adoption of ICT in the US construction industry by applying the Technology Acceptance Model (TAM) developed by Davis (1989). The TAM recognized a relationship with actual use of technology based on the premise of behavioral intent (BI) and intended use and that user perceived usefulness (PU) leads to intended use, which translates to actual use. The TAM also recognizes that user perceived ease of use (PEOU) supports the premise of PU enhancing intended use by increasing the PU. This research used independent variables from previous research to serve as a basis for establishing a benchmark for US construction firms. Seventy-six US construction professionals were surveyed for this study. The results showed that the US construction industry follows the TAM model in that if the technology is perceived to be useful it will be adopted, and this seems to be supported by PEOU. Application of this extended TAM in the US construction industry will help companies predict the successful adoption and use of ICT, allowing managers to make more informed decisions in the adoption process.

KEYWORDS: information and communications technology (ICT), technology acceptance model (TAM), construction, ease of use, usefulness.

REFERENCE: James Sorce, Raja R. A. Issa (2021). Extended Technology Acceptance Model (TAM) for adoption of Information and Communications Technology (ICT) in the US construction industry. Journal of Information Technology in Construction (ITcon), Vol. 26, pg. 227-248, DOI: 10.36680/j.itcon.2021.013

COPYRIGHT: () 2021 The author(s). This is an open access article distributed under the terms of the Creative Commons Attribution 4.0 International (https://creativecommons.org/licenses/by/4.0/), which permits unrestricted use, distribution, and reproduction in any medium, provided the original work is properly cited. 


\section{INTRODUCTION}

Since 1945, productivity in manufacturing, retail and agriculture in the US has grown by as much as 1,500 percent, but productivity in construction has barely increased at all (MGI 2017). Increasing information and communications technology (ICT) use in the US construction industry increases its overall productivity and has the potential to save billions of dollars (Grau et al. 2009, Chou et al. 2014). Lack of ICT evaluation research, and the low level of understanding of the implementation process have impeded US construction companies in deciding what ICTs have the potential to be successfully adopted and embraced by their workforce (Peansupap and Walker 2005). Understanding what attributes an ICT must have, or what needs to be in place for successful ICT adoption in the industry, can yield a higher success rate in ICT integration and use.

The purpose of this research is to develop a list of attributes that will increase the likelihood of successful adoption of ICT in US construction firms. To accomplish this, an extended version of the Technology Acceptance Model (TAM), established by Davis $(1986,1989)$, was applied to the US construction industry to understand factors that lead to ICT adoption. The research questions answered by the application of this extended TAM model are: whether the extended TAM variables correlate with each other and the original TAM model (Q1); whether the extended TAM can better explain the use of ICT in the US construction industry than the original TAM model (Q2); and whether other attributes exist (H30-H80) that are of interest to US construction firms in selecting new ICT (Q3). Table 1 shows the eight Null Hypotheses tested to answer questions Q1- Q3.

This study explores ICT uses in the US construction industry including computer software; computer integration; BIM applications; Internet applications; cloud computing; RFID tracking; laser scanning; and mobile/handheld devices. It recognizes the differences between project-level, solution-based initiatives, strategic firm-wide ICT initiatives, and industry-wide innovation trends. The impact of company-support on the use of these technologies, their adoption and use were studied. While training and education were not tested directly in the survey, company dedication to support use of ICT is included as ICT facilitating conditions.

Table 1. Null Hypotheses tested for US construction industry

\begin{tabular}{ll}
\hline \multicolumn{1}{c}{ Null Hypothesis } \\
\hline $\mathrm{H} 1$ o
\end{tabular}

\section{BACKGROUND}

Technological innovation and adoption strategies have been under development and study since the late 20th century. Five of these pervading strategies and theories related to technology acceptance and adoption success modeling which provide context to this study are reviewed next: Technology Acceptance Model (TAM); ICT Adoption in the US Construction Industry, United Theory of Acceptance and Use of Technology (UTAUT); ICT Integration and increases in Productivity; and a Culture of Innovation. Basic understanding of these theories provides context to the goals of influential factor identification and review in this study which lays the groundwork for the development of practical strategies to improve ICT integration success. 


\subsection{Technology Acceptance Model (TAM)}

The TAM has been applied in several industries and adapted in several instances to explain the adoption of technology. TAM is applicable to the construction industry in that it seeks to evaluate the potential for success of technological adoption at the individual level through two main variables: (PU) and perceived ease of use (PEOU). To this end, TAM has been used for a variety of topics ranging from Smart Construction System success to BIM acceptance (Lee et al. 2003; Lee et al. 2015; Liu et al 2015). The TAM can predict up to 50 percent of user acceptance of technology (Davis 1989, Park 2009), while other extended TAM models explained more of the intended use by adding attributes. In this section a literature review is conducted on the application of the Technology Acceptance Model (TAM) in US industry. The project, company- and industry-wide attributes that influence the adoption of ICT in the US construction industry are also determined from existing literature. UTAUT is then reviewed to consider social influences and environmental factors not considered in the TAM model. Next ICT and its impact on US construction productivity and the culture of innovation and its impact on technology adoption is explored. The information extracted from this background is used to develop a comparison matrix showing the parameters measured by TAM, Modified TAM and this study on the US construction industry, which is then used to develop the survey questionnaire administered in this study.

Davis et al. (1989) also found that the TAM and the Theory of Reasoned Action (TRA) (Ajzen and Fishbein 1980) significantly predicted behavior when the TRA included behavioral intent (BI) based on social and internal imposed norms. They concluded that ICT use could be predicted by an individual's BI, PU, and PEOU. The TAM is less general that the TRA and is applied to only computer usage behavior. Davis et al. (1989) concluded that computer use can be predicted from intentions, which are determined by PU, and significantly influenced by PEOU. Davis (1989) noted other factors that influenced technology use in development of the TAM including self-efficacy, cost-benefit paradigm related to the firm's approach to the technology, and the actual attributes of the technology, specifically: compatibility, complexity and relative advantage. Several previous US studies showed that TAM transcends industries, applies across disciplines and can be used to predict behavior regardless of application (Davis 1989; Venkatesh and Davis 2000). Ismail (2002) proposed revisions to TAM adding three concepts: voluntariness, image and result demonstrability, resulting in the creation of the TAM2.

The Diffusion of Innovation Theory (DOI) was developed using the following attributes: observability, relative advantage, compatibility, trialability and complexity (Rogers 1995). Ismail (2012) incorporated consumer decisions in the theory of technology adoption using the DOI and showed that there is a connection between a customer's perceptions of utility and adoption intentions in utilization of the Apple iPhone. He concluded that if US construction companies can predict the utilization of a new ICT, they can better predict success, total cost of implementation and ownership and complete a more accurate cost-benefit analysis. Gambatese and Hallowell (2011) sought to determine and evaluate the major factors which influenced the initiation, development and diffusion of technological innovation in the construction industry and found that increased innovation and diffusion could be realized through increases in communication, encouragement from upper management for teams to try new things, and formal innovation meetings.

\subsection{ICT Adoption in the US Construction Industry}

Innovation in construction is driven by industry-level solutions, firm-level solutions, and project-level solutions, motivated by project complexity, innovation policy, and environmental sustainability (Mitropoulos and Tatum 1999, Ozorhon and Oral 2016). Peansupap and Walker (2005) cited complexity, relative advantage and compatibility as factors influencing technology adoption in US construction firms. Table 2 shows the project level attributes that were found to influence the adoption of ICT in the US construction industry.

Tables 3 and 4 show the company- and industry-wide ICT attributes previously cited. ICT utilization in construction provides potential for companies to build and maintain an advantage. Unfortunately, construction companies tend to lag and are not at the same level of ICT adoption as most other industries (Zhai et al. 2009, Teizer et al. 2013) Peansupap and Walker (2005) found that the size of a construction company is not necessarily a factor in the adoption of ICT as most studies in ICT adoption are based on large firms (Zhu 2009). 
Table 2: Project level US ICT attributes.

\begin{tabular}{|c|c|c|c|}
\hline $\begin{array}{l}\text { Project-Related } \\
\text { Attribute }\end{array}$ & Explanation & Source & $\begin{array}{c}\text { Tested } \\
\text { (This study) }\end{array}$ \\
\hline Client requirements & $\begin{array}{l}\text { Industry is driven by needs of owners and } \\
\text { standards to affect solutions to construction. }\end{array}$ & $\begin{array}{l}\text { Brandon and } \mathrm{Lu} \\
(2008) \text {. }\end{array}$ & $\begin{array}{l}\text { Industry } \\
\text { Influence }\end{array}$ \\
\hline $\begin{array}{l}\text { Improving project } \\
\text { performance }\end{array}$ & $\begin{array}{l}\text { Project cost, quality, and client satisfaction } \\
\text { drive projects to offer better products for } \\
\text { clients and improve the bottom line. }\end{array}$ & $\begin{array}{l}\text { Goodrum and Haas } \\
\text { (2004). }\end{array}$ & Usefulness \\
\hline $\begin{array}{l}\text { Approach of the } \\
\text { project team }\end{array}$ & $\begin{array}{l}\text { Renewed approaches to project delivery } \\
\text { methods create cultures that are interested in } \\
\text { creating better solutions rather than low cost. }\end{array}$ & Egan (1998). & $\begin{array}{l}\text { Quality of } \\
\text { output }\end{array}$ \\
\hline Cost savings & $\begin{array}{l}\text { Technology creates an ability to reduce cost } \\
\text { of transaction time and cost of automation of } \\
\text { the business process. }\end{array}$ & Issa et al. (2003). & Usefulness \\
\hline Complexity & $\begin{array}{l}\text { Project complexity creates need for } \\
\text { technological approaches base on the unique } \\
\text { nature of the industry. }\end{array}$ & $\begin{array}{l}\text { Williams et al. } \\
\text { (2007); Keegan and } \\
\text { Turner (2002). }\end{array}$ & Usefulness \\
\hline
\end{tabular}

Table 3: Company-wide US ICT attributes.

\begin{tabular}{|c|c|c|c|}
\hline $\begin{array}{c}\text { Firm-Related } \\
\text { Attribute } \\
\end{array}$ & Explanation & Source & $\begin{array}{c}\text { Tested } \\
\text { (This study) }\end{array}$ \\
\hline $\begin{array}{l}\text { Competitive } \\
\text { advantage }\end{array}$ & $\begin{array}{l}\text { Firms can create an edge to help compete in } \\
\text { the market by embracing and utilizing ICT. }\end{array}$ & $\begin{array}{l}\text { Mitropoulos and Tatum } \\
\text { (1999) }\end{array}$ & Industry Influence \\
\hline $\begin{array}{l}\text { Knowledge } \\
\text { Sharing }\end{array}$ & $\begin{array}{l}\text { Companies share information and produce } \\
\text { useable communication to stakeholders } \\
\text { creating a need to innovate. }\end{array}$ & $\begin{array}{l}\text { Peansupap and Walker } \\
\text { (2005). }\end{array}$ & Compatibility \\
\hline $\begin{array}{l}\text { Client/supplier } \\
\text { relationship }\end{array}$ & $\begin{array}{l}\text { Technology created the ability to manage } \\
\text { supplier and vendor relationships creating a } \\
\text { formidable network. }\end{array}$ & Issa et al. (2003). & Industry Influence \\
\hline $\begin{array}{l}\text { Improving firm } \\
\text { performance }\end{array}$ & $\begin{array}{l}\text { To thrive in the industry companies must } \\
\text { create a competitive advantage based on the } \\
\text { nature of competition. }\end{array}$ & Slaughter (2000). & Usefulness \\
\hline $\begin{array}{l}\text { Corporate social } \\
\text { responsibility }\end{array}$ & $\begin{array}{l}\text { Improves client satisfaction and creates } \\
\text { goodwill for the public creating a better image }\end{array}$ & Green (2008). & Industry Influence \\
\hline $\begin{array}{l}\text { Leadership/ mgmt. } \\
\text { enthusiasm }\end{array}$ & $\begin{array}{l}\text { Leading industry in innovation creates cyclica } \\
\text { motivation that drives further innovation. }\end{array}$ & $\begin{array}{l}\text { Williams et al. (2007); } \\
\text { Ozorhon et al. (2014). }\end{array}$ & Self-efficacy \\
\hline Staff & $\begin{array}{l}\text { Dedicated tech savvy people influence the } \\
\text { ability and drive to innovate. }\end{array}$ & Williams et al. (2007). & $\begin{array}{l}\text { E-commerce use/E- } \\
\text { business utilization }\end{array}$ \\
\hline $\begin{array}{l}\text { Innovation } \\
\text { policy }\end{array}$ & $\begin{array}{l}\text { Culture of innovation creates a drive to find } \\
\text { better ICT solutions. }\end{array}$ & Davies et al. (2014). & $\begin{array}{l}\text { Facilitating } \\
\text { Conditions/Culture } \\
\text { of Innovation }\end{array}$ \\
\hline
\end{tabular}

Table 4: Industry-wide US ICT attributes.

\begin{tabular}{|c|c|c|c|}
\hline $\begin{array}{c}\text { Industry-Related } \\
\text { Attribute }\end{array}$ & Explanation & Source & $\begin{array}{c}\text { Tested } \\
\text { (This study) }\end{array}$ \\
\hline
\end{tabular}




\begin{tabular}{|c|c|c|c|}
\hline Competition & $\begin{array}{l}\text { Bids are won by companies that create innovative } \\
\text { solutions. This drives the market to be better. }\end{array}$ & $\begin{array}{l}\text { Nam and Tatum } \\
\text { (1992) }\end{array}$ & $\begin{array}{l}\text { Industry } \\
\text { Influence }\end{array}$ \\
\hline $\begin{array}{l}\text { External factors: } \\
\text { Regulations and } \\
\text { legislation / Pressure }\end{array}$ & $\begin{array}{l}\text { Governmental rules and regulations force } \\
\text { construction firms to innovate to comply with new } \\
\text { laws in the market and to meet new codes in } \\
\text { construction. }\end{array}$ & $\begin{array}{l}\text { Reichstein et al. } \\
\text { (2008); } \\
\text { Mitropoulos and } \\
\text { Tatum (2000) }\end{array}$ & Not tested \\
\hline Trends in technology & $\begin{array}{l}\text { Owners tend to expect companies to use the current } \\
\text { standards and proven emerging tech. to create } \\
\text { innovation in project solutions. }\end{array}$ & $\begin{array}{l}\text { Blayse and Manley } \\
\text { (2004) }\end{array}$ & $\begin{array}{l}\text { Industry } \\
\text { Influence }\end{array}$ \\
\hline $\begin{array}{l}\text { Environmental } \\
\text { sustainability }\end{array}$ & $\begin{array}{l}\text { Green construction trends are driving construction } \\
\text { firms to create new solutions to meet } \\
\text { environmental challenges. }\end{array}$ & $\begin{array}{l}\text { Miozzo and } \\
\text { Dewick (2004) }\end{array}$ & $\begin{array}{l}\text { Industry } \\
\text { Influence }\end{array}$ \\
\hline Reward schemes & $\begin{array}{l}\text { Reward for innovation drives companies to pursue } \\
\text { grants, awards, and other gov. programs. }\end{array}$ & $\begin{array}{l}\text { Ozorhon et al. } \\
\text { (2010) }\end{array}$ & Not tested \\
\hline Compatibility & $\begin{array}{l}\text { Being able to mesh with other partners in the } \\
\text { industry is a key component of motivation to } \\
\text { innovate. Project requirements force companies to } \\
\text { adopt technologies to communicate effectively. }\end{array}$ & $\begin{array}{l}\text { Peansupap and } \\
\text { Walker (2005) }\end{array}$ & Compatibility \\
\hline
\end{tabular}

\subsection{The Unified Theory of Adoption and Utilization of Technology (UTAUT)}

The Unified Theory of Adoption and Utilization of Technology (UTAUT) is another theoretical model used to explain the adoption of a technology and is based on the theory of TAM (Gonzales et al. 2012). UTAUT considers social influences and environmental factors not considered in the TAM model including performance expectancy, effort expectancy, social influence, and facilitating conditions and it recognizes that intention, in turn, predicts technology use (Brown et al. 2010 and Venkatesh et al. 2003). The UTAUT synthesizes known conditions for assessment of the likelihood of technology adoption (Venkatesh et al. 2003) and highlights the need for a structural framework that guides the adoption and utilization of technology in firms. Gonzalez et al. (2012) used the UTAUT to explore the intention of businesses to adopt continuous monitoring technology(CMT) and assumed that the intentions of the organization are dependent on the intentions of the individuals in the firm and eliminated individual demographics from their UTAUT. Their findings are in line with the TAM assertion that PU is the most significant factor in the adoption of new technology, where performance expectancy is equivalent to PU but on the firm level. Facilitating conditions and social influence were also determinants of CMT adoption and effort expectancy was found to not be significant in its adoption (Gonzalez et al. 2012).

Venkatesh et al. (2012) established UTAUT2 incorporating constructs to better explain the consumer's adoption of technology. Hedonic motivation, price value, and experience and habit were added to the UTAUT model to encompass consumer behavioral traits to add to the predictive ability of the UTAUT (Venkatesh et al. 2012). UTAUT2 showed that there is a correlation between personal habit and use of technology (Venkatesh et al. 2012) and concluded that personal technology use increased the likelihood of technology adoption and use. Buchanan et al. 2013 concluded that a consensus on a complete model that is a true predictor of technology use has not been reached and that while the existing models allow managers to better predict use, they fall short in some applications. Furthermore, they opined that the ability to predict use and adoption also has implications in developing training and educational materials for newly implemented technology.

\subsection{ICT Integration and Increases in Productivity}

Construction companies must identify processes that would benefit from the implementation of ICT, while considering cost effectiveness (Grau et al. 2009), keeping in mind that proper integration is necessary to realize the full potential of ICT. There are many different areas where ICT can have an impact on productivity. Access to real-time data monitoring resources on construction projects can lead to a more productive project (Teizer et al. 2013; Costin et al. 2015). The expectations for ICT are that it will give companies the ability to control an everincreasing project complexity (Grau et al. 2009). The construction industry needs to establish a greater integration of technology to increase productivity based on the decreasing skill of laborers, as it has been established in manufacturing (Goodrum and Haas 2004). 
ICT increases productivity in many aspects of most industries and construction is not an exception, however, this may be impacted by an increase in administrative costs for implementing technology (Grau et al. 2009). ICT will have a similar impact on the construction industry that it has had on other worker productivity in the world (Zhai et al. 2009). Increasing the industry's computing power and decreasing cost will lead to higher integration and use of ICT, thus increasing productivity (Mačiulytė-Šniukienė and Gaile-

Sarkane 2014). Since productivity increases profits, an increase in labor productivity may be enough for the construction industry to gain motivation in the adoption and integration of technology (Zhai et al. 2009).

Labor productivity can be considered one of the most important aspects of construction projects, as labor cost can be up to 50\% of total construction costs (Menon and Varghese 2018). Chou et al. (2014) showed that there is a positive relationship between increasing automation and the integration of ICT on construction projects. ICT integration creates connections between trade partners, customers, and suppliers and has a positive impact on value creation (Soroor et al. 2009). These connections created by ICT, aid in creating better products, establish higher quality, create enhanced equipment utilization, reduce resource needs, and increase flexibility (Kim and Narasimhan 2002). Goodrum and Haas (2004) categorized how specific technology factors affected productivity and focused their research on equipment and tools using a commercially available cost database.

Radio Frequency Identification (RFID) systems have created a simplistic system for materials tracking that can eliminate delays and lead to an increase in productivity in comparison to manual tracking systems (Grau et al. 2009). Kereri and Adamtey (2019) found that the most important key driver for RFID adoption is productivity improvement, while the most important critical success factors include management support and commitment, having clear RFID strategy, needs and benefits, having strong motivation for improvement, providing adequate funding and proper planning. Costin et al. (2015) showed that integrating ICT, in the form of RFID tags on workers, equipment and materials linked to a BIM model, could improve job site safety, ensure compliance with specific regulations related to personnel, reduce time for location of equipment and materials, reduce rework due to asset traffic in finished areas, increase planning capabilities for subcontractors, and enhance time billing capabilities based on worker tracking. Tong et al. (2015) attributed the success of BIM to its TAM2 attributes that encompassed all building stages coordinated with the stakeholders on the project.

All these models impact the development of training and educational materials to aid in the adoption and utilization of ICT. Companies must develop a mechanism for managing the lifecycle of a true predictor of technology use. These models show what influenced adoption and, to some extent, predict the level of utilization of ICT in firms and by individuals. A less ICT savvy workforce requires greater care to ensure proper utilization. Buchanan et al. (2013) pointed out that TAM lacks in attributing education and training influence on adoption in ICT efficacy and that ICT education and training increased PEOU and the likelihood of successful integration. They also noted the impact of "culture" on ICT adoption and use. The cost effectiveness of ICT can be difficult to calculate because of the many different factors that affect a project which make a cause and effect relationship difficult to establish (Mačiulytė-Šniukienè and Gaile-Sarkane 2014). Once committed to a culture of technology and innovation, maintaining a competitive advantage requires continuous ICT upgrade to keep up if not to stay ahead (Gonzales et al. 2012).

\subsection{Culture of Innovation}

Traditionally, companies wait for ICT to mature before integrating them into their workflows and they are more likely to adopt technologies that stakeholders utilize (Andriole 2014). The swiftness of the adaptation of the iPad is a direct result of companies adopting the habits of their stakeholders (Andriole 2014). Innovation emerges from the market based on an historic challenge (Denning 2014). Firms must embrace a culture of innovation and build a strategic plan for adaptation to alleviate detrimental technological adoptions. Rave-Habhab (2011) showed an underlying relationship of mutual influence between innovation and corporate culture. Without this built-in culture of innovation firms are not able to effectively embrace new technologies and will fall short (Malek et al. 2012). Zhu (2009) found that most studies in technology are based on large firms. Even so, there may be little difference when it comes to the adoption of specific types of ICT in construction firms. ICT is essential in the construction industry and increased ICT in construction firms has a positive effect on overall efficiency (Mitropoulos and Tatum 1999; Issa et al. 2003; Peansupap and Walker 2005).

\subsection{TAM Model Summary}

Table 5 shows the different TAM models reviewed in this study and compares their tested attributes to the attributes used in this study. Factors perceived to increase the likelihood of ICT adoption/utilization in the 
construction industry and make construction projects more efficient and increase profits were selected (see Table $1)$.

Table 5: Comparison of parameters measured by TAM and Modified TAM and this study.

\begin{tabular}{|c|c|c|c|c|c|c|c|}
\hline $\begin{array}{l}\text { Parameters Measured } \\
\text { (Variable: Definition) }\end{array}$ & $\sum_{\leftarrow}$ & $\sum_{1}^{N}$ & 占 & 空 & $\underset{\underbrace{}}{\nwarrow}$ & อ̆ & 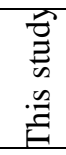 \\
\hline Behavior: Action of individual of interest & & & & & $\checkmark$ & & \\
\hline $\begin{array}{l}\text { Attitude/Behavioral beliefs: Individual's predisposition } \\
\text { toward behavior. }\end{array}$ & & & & & $\checkmark$ & & \\
\hline $\begin{array}{l}\text { Subjective Norm / Social Influence: Individual's perception } \\
\text { of the degree to which others approve or disapprove of target } \\
\text { behavior. }\end{array}$ & & $\checkmark$ & $\checkmark$ & $\checkmark$ & $\checkmark$ & & \\
\hline $\begin{array}{l}\text { Perceived Usefulness (PU): Individual's perception that } \\
\text { using technology will enhance job performance. }\end{array}$ & $\checkmark$ & $\checkmark$ & $\checkmark$ & $\checkmark$ & & & $\checkmark$ \\
\hline $\begin{array}{l}\text { Perceived Ease of Use (PEOU): Individual's perception that } \\
\text { using technology will be free of effort. }\end{array}$ & $\checkmark$ & $\checkmark$ & $\checkmark$ & $\checkmark$ & & $\checkmark$ & $\checkmark$ \\
\hline $\begin{array}{l}\text { Complexity Intention or use (BI): Motivation or willingness } \\
\text { to exert effort to perform a task. }\end{array}$ & $\checkmark$ & $\checkmark$ & $\checkmark$ & $\checkmark$ & & & $\checkmark$ \\
\hline $\begin{array}{l}\text { Use/Behavior: Behavior of interest performed by individual } \\
\text { with regards to a technology. }\end{array}$ & $\checkmark$ & $\checkmark$ & $\checkmark$ & $\checkmark$ & & & $\checkmark$ \\
\hline $\begin{array}{l}\text { Facilitating Conditions/Culture of Innovation: Atmosphere / } \\
\text { Factors that support or impede the target behavior. }\end{array}$ & & & $\checkmark$ & $\checkmark$ & & & $\checkmark$ \\
\hline $\begin{array}{l}\text { Performance Expectancy: Includes PU, Extrinsic } \\
\text { Motivation, job-fit, Relative advantage and outcome } \\
\text { expectations. }\end{array}$ & & & $\checkmark$ & $\checkmark$ & & & \\
\hline $\begin{array}{l}\text { Effort Expectancy: Includes PEOU, Complexity, and Ease } \\
\text { of use. }\end{array}$ & & & $\checkmark$ & $\checkmark$ & & & \\
\hline $\begin{array}{l}\text { Experience and Habit: Individual's Level of skill with } \\
\text { technology. }\end{array}$ & & & & $\checkmark$ & & & \\
\hline $\begin{array}{l}\text { Hedonic Motivation: Fun or pleasure derived from using } \\
\text { technology. }\end{array}$ & & & & $\checkmark$ & & & \\
\hline Price Value: Consumer bears the cost & & & & $\checkmark$ & & & \\
\hline $\begin{array}{l}\text { E-commerce use / E-business utilization: Use of technology } \\
\text { to perform business transactions. }\end{array}$ & & & & & & & $\checkmark$ \\
\hline Cost: Total cost to adopt. & & & & & & & $\checkmark$ \\
\hline Quality of output: Relevance of data produced. & & & & & & & $\checkmark$ \\
\hline $\begin{array}{l}\text { Compatibility: Ability to coexist within industry's current } \\
\text { technology. }\end{array}$ & & & & & & $\checkmark$ & $\checkmark$ \\
\hline $\begin{array}{l}\text { Industry Influence: Pressure from market to utilize } \\
\text { technology. }\end{array}$ & & & & & & & $\checkmark$ \\
\hline $\begin{array}{l}\text { Relative Advantage: Degree that innovation is perceived } \\
\text { better than what was used prior. }\end{array}$ & & & & & & $\checkmark$ & \\
\hline $\begin{array}{l}\text { Demonstrability: Degree to which the technology can be } \\
\text { shown to users. }\end{array}$ & & & & & & $\checkmark$ & \\
\hline Image: Perceived Status of the technology & & & & & & $\checkmark$ & \\
\hline $\begin{array}{l}\text { Trialability: Degree to which the technology can be } \\
\text { experimented with prior to adoption. }\end{array}$ & & & & & & $\checkmark$ & \\
\hline $\begin{array}{l}\text { Voluntariness: The extent to which the individual is free to } \\
\text { choose to perform the target behavior. }\end{array}$ & & & & & & $\checkmark$ & \\
\hline
\end{tabular}




\section{METHODOLOGY}

This research is focused on determining and discovering what attributes are most important in increasing the likelihood of ICT adoption and acceptance in the US construction industry. The purpose of this work is not to provide a comprehensive and in-depth literature review of the various ICT integration models over time. Rather, the goal is to provide context for widely accepted and published models based on seminal works (and some subsequent works with meaningful citation history) while focusing on the contribution of this work itself being US construction industry specific factor identification. The goal is less theoretical and is focused on laying the groundwork for the development of a practical understanding of ICT integration in the US construction industry.

Survey respondents for this study were selected from US participants in construction management career fairs at the University of Florida and the University of North Florida and were based on existing relationships with construction professionals made through industry interaction over the years. The survey was thus distributed to a convenience sample of US construction industry professionals and targeted US construction industry ICT users from both the Decision Makers (DM) and Users (U) groups. Respondents were asked questions on: current use of ICT, their ability to influence company decisions on use: PU; PEOU; e-business/e-commerce (E-Biz); compatibility (Comp); quality of output (QOP); relative industry influence (Industry); and company's current culture/facilitating conditions surrounding use of ICT (Cult).

Other questions targeted the respondents' demographics and were related to the adoption and use of ICT in the US construction industry and were based on previous studies in the TAM and related studies connected to the construction industry (see Table 6). These attributes are: PU, PEOU, cost analysis, quality of output, social influence, compatibility and facilitating conditions (Venkatesh et al. 2003) and e-commerce use (Fayad 2006)/ebusiness (Issa et al. 2003). These variables were adapted for the nature of the construction and are consistent with attributes tested in the TAM, TAM2, UTAUT, and the UTAUT2 models.

The respondent's job role could impact how they perceived computer technology (Hernández et al. 2008). Therefore, they were asked about their role in the adoption and use of ICT in their company and what the potential for their company was to accept their suggestions regarding the adoption of new ICT. The questions were also targeted to help determine what ICT attributes were important. Construction companies were found to be more open to ICT solutions designed specifically for the US construction industry (Issa et al. 2003). Consequently, the findings of this research would help US companies adopt ICT that met their criteria and indicate what is needed to help propagate ICT integration.

\section{RESULTS}

\subsection{Descriptive Statistics}

General contractors (GCs) were targeted in the study and 67 of the total of 76 respondents were from this category with the rest being subcontractors (5), owner representatives (contractors acting as such) (3) and construction consultant (1). GCs were targeted to develop an understanding of ICT use in the US construction industry from the companies that use it and disseminate it to other levels of the industry. The demographics were used in a regression model to test whether any played a role in predicting of use and adoption of ICT in the construction industry. There were no significant demographics found in the analysis other than company size. Most of the respondents (83\%) were between the ages of 23 and 39 and most (65\%) were male.

The Decision Makers (DM) group was comprised of 63 respondents while the User group consisted of 13. Twentysix percent of respondents worked for US companies that were considered a "small business" according to Title 13, US Code of Federal Regulations, part 121. An annual volume of under $\$ 5$ million was reported by 8 respondents; 20 reported annual sales from over $\$ 5$ million to $\$ 100$ million, 30 reported sales of over $\$ 100$ million to under $\$ 1$ billion and 18 had annual sales ranging from over $\$ 1$ billion up to $\$ 10$ billion. About two-thirds of the companies (50) had annual sales in the range of $\$ 5$ million to under $\$ 1$ billion.

Table 6 shows the different types of ICT and the number of respondents using them and the basis for the dependent variable Actual use. ICT is listed in declining order of use in the respondents' firms. The Cronbach $\alpha$ coefficient was calculated for the sets of questions to verify the internal validity to confirm that the recorded data trended in the same way. Most of the groups of questions in the survey had Cronbach $\alpha$ coefficients at or above 0.7. The exceptions to this were the industry standard and cost related questions which had corresponding Cronbach $\alpha$ coefficients of 0.574 and 0.348 respectively. Grouping the questions for "Cost1, Cost2 and Cost3" resolved this 
and yielded a coefficient of 0.795 . However, "Cost4, Cost5, and Cost6" seem unrelated with a Cronbach $\alpha$ coefficient of -0.833 . Different combinations of the Cost variables were used, and no correlation was found. These results are attributed to the wording of Cost4-Cost6 questions which included the phrase "serious implications," which might have differing meanings to the respondents.

Table 6: ICT use frequency and percentages.

\begin{tabular}{|c|c|c|}
\hline ICT & Companies Using & Percentage \\
\hline Email & 76 & $100 \%$ \\
\hline Accounting Software & 74 & $97 \%$ \\
\hline Word Processing & 73 & $96 \%$ \\
\hline Scheduling Software & 72 & $95 \%$ \\
\hline Tablet or Smart Phone for Data Collection & 64 & $84 \%$ \\
\hline Digital Plans & 63 & $83 \%$ \\
\hline Internet/Wireless Technology & 62 & $82 \%$ \\
\hline Project Management Software & 58 & $76 \%$ \\
\hline Estimating Software & 58 & $76 \%$ \\
\hline Quantity Takeoff Technology & 55 & $72 \%$ \\
\hline File Storage and Collaboration Software & 54 & $71 \%$ \\
\hline Invitation to Bid ITB/ plan room & 52 & $68 \%$ \\
\hline CAD Drawings & 49 & $64 \%$ \\
\hline Conferencing and Communications Software & 48 & $63 \%$ \\
\hline E-Commerce & 44 & $58 \%$ \\
\hline Cloud Computing Technology & 43 & $57 \%$ \\
\hline Hand-held Smart Application Technology & 42 & $55 \%$ \\
\hline BIM 3D & 41 & $54 \%$ \\
\hline Online Bidding & 33 & $43 \%$ \\
\hline Database/Knowledge Management & 32 & $42 \%$ \\
\hline Prequalification Software & 30 & $39 \%$ \\
\hline Drone Technology & 30 & $39 \%$ \\
\hline In-House Proprietary Software & 30 & $39 \%$ \\
\hline BIM Clash Detection & 28 & $37 \%$ \\
\hline Web Based Project Collaboration & 24 & $32 \%$ \\
\hline Collaboration Technology & 23 & $30 \%$ \\
\hline Web Based Project Tracking & 23 & $30 \%$ \\
\hline GPS Materials Tracking Technology & 22 & $29 \%$ \\
\hline 3D Scanning & 22 & $29 \%$ \\
\hline Client Relationship Management Software & 22 & $29 \%$ \\
\hline BIM 4D & 18 & $24 \%$ \\
\hline Virtual Reality & 18 & $24 \%$ \\
\hline Mobile BIM Technology & 17 & $22 \%$ \\
\hline E-Procurement & 17 & $22 \%$ \\
\hline Building Scanning Technology & 16 & $21 \%$ \\
\hline Materials Tracking & 16 & $21 \%$ \\
\hline Web Based Cost Estimating & 15 & $20 \%$ \\
\hline Wearable Devices & 13 & $17 \%$ \\
\hline BIM 5D & 11 & $14 \%$ \\
\hline Augmented Reality & 11 & $14 \%$ \\
\hline BIM 6D & 9 & $12 \%$ \\
\hline 3D Printing & 9 & $12 \%$ \\
\hline Earthwork 3D Modeling & 1 & $1 \%$ \\
\hline
\end{tabular}

\subsection{Reliability}

PEOU was not tested for a valid Cronbach $\alpha$ due to the random selection of questions given to the respondents resulting in some respondents receiving only four out of the seven of survey questions related to PEOU. Table 7 shows the correlations between questions for the PEOU variable for those respondents who received all seven questions. Although not all the questions were correlated, some correlations, at the $90 \%$ confidence level, between 
the responses were found (grey cells in Table 7). The set of questions related to PEOU indicated that only some of the respondents' data trended in the same way. This indicated that respondents had differing opinions when faced with tradeoff between PEOU and other attributes, even though PEOU was ranked highly in importance at the beginning of the survey. The lack of consistency could also be attributed to a group of respondents not receiving all the questions. Some respondents, based on their role in the process of adoption, could also have differing opinions on the need for easy-to-use software. One would expect that PEOU would be of more importance to the Users than the Decision Makers group. The large number of respondents that were involved in the decision-making process could also be a factor in skewing the results for this set of questions.

Table 7: Correlations between PEOU questions combining Decision Makers and Users.

\begin{tabular}{|c|c|c|c|c|c|c|}
\hline \multicolumn{7}{|c|}{ PEOU1_DM_UPEOU2_DM_UPEOU3_DM_UPEOU4_DM_UPEOU5_DM_UPEOU6_DM_U } \\
\hline \multirow[t]{2}{*}{ PEOU2_DM_U } & -0.296 & & & & & \\
\hline & 0.057 & & & & & \\
\hline \multirow[t]{2}{*}{ PEOU3_DM_U } & 0.332 & 0.278 & & & & \\
\hline & 0.020 & 0.075 & & & & \\
\hline \multirow[t]{2}{*}{ PEOU4_DM_U } & 0.071 & 0.205 & 0.253 & & & \\
\hline & 0.666 & 0.211 & 0.120 & & & \\
\hline \multirow[t]{2}{*}{ PEOU5_DM_U } & 0.011 & 0.009 & 0.035 & -0.134 & & \\
\hline & 0.945 & 0.954 & 0.822 & 0.415 & & \\
\hline \multirow[t]{2}{*}{ PEOU6_DM_U } & 0.031 & -0.099 & 0.168 & 0.172 & -0.150 & \\
\hline & 0.850 & 0.545 & 0.301 & 0.295 & 0.354 & \\
\hline \multirow[t]{2}{*}{ PEOU7_DM_U } & -0.122 & -0.047 & 0.206 & -0.054 & 0.072 & 0.184 \\
\hline & 0.440 & 0.768 & 0.190 & 0.744 & 0.650 & 0.256 \\
\hline
\end{tabular}

Note: Question 1, $\mathrm{n}=48$, Question 2, $\mathrm{n}=41$, Question 3, $\mathrm{n}=48$, Question 4, $\mathrm{n}=38$, Question 5, $\mathrm{n}=42$, Question 6, $\mathrm{n}=39$ and Question 7, $\mathrm{n}=41$.

\subsection{Descriptive Statistics of the Variables}

Survey respondents were asked to rate their current computer use and skills level and the response data was labeled Self1. The respondents were asked to rate themselves on a sliding Likert scale from 3 to -3 with 0 being neutral. The Self1 analysis yielded a mean score of 1.99 indicating a higher than average self-reported level of computer use/skill level and the minimum score was 0.00 indicating that the respondent had a higher than average comfort level in the use of ICT. Self-efficacy was indicated in the literature as having an impact on technology use.

The attributes were ranked in importance from 1 (highest) to 7 (lowest), with PU ranked as 1 in importance by $34.2 \%$ and PEOU by $22.4 \%$ of the respondents. PU was ranked number 2 in importance by $22.4 \%$ and PEOU by $30.3 \%$. The results support the premise of the original TAM in showing that $P U$ and $P E O U$ are most important in predicting actual use of technology. Other variables that scored relatively high in the ranking were Quality of Product ( $Q O P$ ) $21.1 \%$ and Company Support (Cult) $14.5 \%$. Low scoring variables included Compatibility to subs (Comp) $4.0 \%$, Cost to implement (Cost) $2.63 \%$ and Current industry use (Industry) $1.3 \%$.

Table 8 shows the descriptive statistics of how each of the aforementioned variables were ranked with $P U$ and $P E O U$ showing the highest rankings of all attributes. $P U$ had the lowest mean of all rankings at 2.6 and it was on average picked as the highest ranked attribute by the most respondents whereas PEOU rated second with a mean of 2.8. Both $P U$ and PEOU had a median score of 2 and a mode of 1 and 2, respectively. $Q O P$ had a mean of 3.1, median of 3, and mode of 3, placing it in the top scoring of the rankings. Company support ( $C$ ult) showed importance with a slightly lower ranking than $Q O P$ ranked with a mean of 3.9, median of 4 and mode of 4. Comp and Cost were rated at the lowest rankings respectively with mean of 4.7 and 4.9, median of 5 each and mode of 6 and 4. 
Table 8: Descriptive statistics of "Rank" question.

\begin{tabular}{|c|c|c|c|c|c|c|c|}
\hline Rank & $\begin{array}{l}\text { Usefulness } \\
\text { in task } \\
\text { completion } \\
\text { (PEOU) }\end{array}$ & $\begin{array}{l}\text { Easy } \\
\text { to } \\
\text { use } \\
(P U)\end{array}$ & $\begin{array}{l}\text { Minimal } \\
\text { cost to } \\
\text { implement } \\
(\text { Cost })\end{array}$ & $\begin{array}{l}\text { Quality } \\
\text { of the } \\
\text { output } \\
(Q O P)\end{array}$ & $\begin{array}{l}\text { Current } \\
\text { Industry } \\
\text { use } \\
\text { (Industry) }\end{array}$ & $\begin{array}{l}\text { Compatibility to } \\
\text { subs of your } \\
\text { current } \\
\text { technology } \\
\qquad \text { (Comp) }\end{array}$ & $\begin{array}{l}\text { Company } \\
\text { support in tech. } \\
\text { use and } \\
\text { adoption } \\
(\text { Cult })\end{array}$ \\
\hline Min & 1.00 & 1.00 & 1.00 & 1.00 & 1.00 & 1.00 & 1.00 \\
\hline Max & 7.00 & 6.00 & 7.00 & 7.00 & 7.00 & 7.00 & 7.00 \\
\hline Mean & 2.63 & 2.82 & 4.91 & 3.12 & 5.83 & 4.72 & 3.97 \\
\hline Median & 2 & 2 & 5 & 3 & 6 & 5 & 4 \\
\hline Std. Deviation & 1.67 & 1.57 & 1.65 & 1.70 & 1.54 & 1.66 & 1.81 \\
\hline Variance & 2.79 & 2.47 & 2.72 & 2.89 & 2.38 & 2.75 & 3.26 \\
\hline Mode & 1 & 2 & 6 & 3 & 7 & 4 & 4 \\
\hline
\end{tabular}

Table 9 shows the statistical information related to PU responses for the Decision Makers (PU_DM), Users (PU_U), and combined (PU_DM_U) results and its importance in adopting and using ICT in the construction industry. PU4 results were not used in the regression analysis because the question was misinterpreted. This question appeared to be misconstrued by respondents as indicated by the reduction in the mean (Table 9). PU scored relatively high in the questions relating to increasing efficacy of employees PU1, PU2, PU3, PU5, and PU6. In fact, all PU mean values were above 2.0, except for PU3_DM. The Users groups responded with PU slightly higher, recording a slightly higher mean than those in the DM group. The combined statistics indicate a high positive correlation between PU and adoption/use of ICT in the US construction industry.

Table 9: PU question statistic for Decision Makers, Users, and Combined groups

\begin{tabular}{|c|c|c|c|c|c|c|c|c|}
\hline PU\# & Field & Group & Min. & Max. & Mean & $\begin{array}{l}\text { Std. } \\
\text { Dev. }\end{array}$ & Variance & Count \\
\hline \multirow[t]{3}{*}{1} & \multirow[t]{3}{*}{ Increase Work Performance } & PU_DM & -1.00 & 3.00 & 2.22 & 0.88 & 0.78 & 63 \\
\hline & & PU_U & 1.00 & 3.00 & 2.46 & 0.63 & 0.40 & 13 \\
\hline & & PU_DM_U & -1.00 & 3.00 & 2.26 & 0.85 & 0.72 & 76 \\
\hline \multirow[t]{3}{*}{2} & \multirow[t]{3}{*}{ Increase Work Productivity } & PU_DM & -1.00 & 3.00 & 2.37 & 0.86 & 0.74 & 63 \\
\hline & & PU_U & 1.00 & 3.00 & 2.62 & 0.62 & 0.39 & 13 \\
\hline & & PU_DM_U & -1.00 & 3.00 & 2.41 & 0.83 & 0.69 & 76 \\
\hline \multirow[t]{3}{*}{3} & \multirow[t]{3}{*}{ Support Critical Work Tasks } & PU_DM & -1.00 & 3.00 & 1.95 & 0.92 & 0.84 & 63 \\
\hline & & PU_U & 1.00 & 3.00 & 2.31 & 0.72 & 0.52 & 13 \\
\hline & & PU_DM_U & -1.00 & 3.00 & 2.01 & 0.90 & 0.80 & 76 \\
\hline \multirow[t]{3}{*}{5} & \multirow[t]{3}{*}{ Improve Work Quality } & PU_DM & 0.00 & 3.00 & 2.13 & 0.83 & 0.68 & 63 \\
\hline & & PU_U & 1.00 & 3.00 & 2.54 & 0.63 & 0.40 & 13 \\
\hline & & PU_DM_U & 0.00 & 3.00 & 2.33 & 0.77 & 0.59 & 76 \\
\hline \multirow[t]{3}{*}{6} & \multirow[t]{3}{*}{ Increase Work Effectiveness } & PU_DM & 0.00 & 3.00 & 2.29 & 0.79 & 0.62 & 63 \\
\hline & & PU_U & 0.00 & 3.00 & 2.23 & 0.97 & 0.95 & 13 \\
\hline & & PU_DM_U & 0.00 & 3.00 & 2.14 & 0.85 & 0.73 & 76 \\
\hline
\end{tabular}


The original TAM model indicates that PEOU supports PU and leads to more positive perception of the usefulness of technology. Table 10 shows how the Decision Makers (PEOU_DM), Users (PEOU_U), and Combined (PEOU_DM_U) respondents scored PEOU in context of other attributes indicated by the questions asked. Although PEOU was ranked highly in the attribute ranking, both groups of respondents indicated that PEOU is not nearly as important in the adoption and use of ICT. All the questions related to PEOU were not asked of all respondents due to a survey version distribution error. Therefore, a Cronbach $\alpha$ could not be run on the data to determine whether the respondent answers were consistent. Respondents were presented with four out of the seven questions related to PEOU. This could be a factor in the lower values for PEOU. However, the ranking of PEOU indicates its importance. The construction industry is not willing to give up function for easy-to-use ICT, indicating respondents' willingness to accept a steeper learning curve for higher ICT functionality. Even so, they ranked PEOU highly (Table 8). Responses to the questions regarding cost indicated that respondents were willing to sacrifice some functionality for higher cost with only slight changes in intention to adopt. As indicated in the responses, cost becomes more of a factor as functionality of the ICT decreases. The Cost1-3 questions did not correlate with Cost4-6 questions. The wording of the question could be a factor and the respondents might need a clearer definition of "serious implication".

Table 10: PEOU_DM statistics.

\begin{tabular}{|c|c|c|c|c|c|c|c|}
\hline PU\# & Group & Min. & Max. & Mean & Std. Dev. & Var. & Count \\
\hline \multirow{3}{*}{1} & PEOU_DM & -3.00 & 3.00 & 0.41 & 1.84 & 3.37 & 39 \\
\hline & PEOU_U & -3.00 & 2.00 & -0.20 & 1.72 & 2.96 & 10 \\
\hline & PEOU_DM_U & -3.00 & 3.00 & 0.29 & 1.83 & 3.35 & 49 \\
\hline \multirow[t]{3}{*}{2} & PEOU_DM & -3.00 & 3.00 & -0.71 & 1.54 & 2.38 & 34 \\
\hline & PEOU_U & -2.00 & 2.00 & -0.13 & 1.69 & 2.86 & 8 \\
\hline & $\underset{\mathrm{U}}{\mathrm{PEOU}}$ & -3.00 & 3.00 & -0.60 & 1.59 & 2.53 & 42 \\
\hline \multirow[t]{3}{*}{3} & PEOU_DM & -3.00 & 3.00 & -1.03 & 1.53 & 2.33 & 39 \\
\hline & PEOU_U & -3.00 & 1.00 & -1.40 & 1.11 & 1.24 & 10 \\
\hline & $\underset{\mathrm{U}}{\mathrm{PEOU} D \mathrm{DM}}$ & -3.00 & 3.00 & -1.10 & 1.46 & 2.13 & 49 \\
\hline \multirow[t]{3}{*}{4} & PEOU_DM & -3.00 & 2.00 & 0.00 & 1.25 & 1.56 & 36 \\
\hline & PEOU_U & -2.00 & 1.00 & -0.67 & 1.25 & 1.56 & 3 \\
\hline & $\underset{\mathrm{U}}{\mathrm{PEOU} D \mathrm{DM}}$ & -3.00 & 2.00 & -0.05 & 1.26 & 1.59 & 39 \\
\hline \multirow[t]{3}{*}{5} & PEOU_DM & -3.00 & 3.00 & 0.70 & 1.75 & 3.07 & 37 \\
\hline & PEOU_U & -3.00 & 1.00 & 0.50 & 1.61 & 2.58 & 6 \\
\hline & $\underset{\mathrm{U}}{\mathrm{PEOU}}$ & -3.00 & 3.00 & 0.53 & 1.78 & 3.18 & 43 \\
\hline \multirow[t]{3}{*}{6} & PEOU_DM & -2.00 & 2.00 & 0.25 & 1.12 & 1.25 & 32 \\
\hline & PEOU_U & -2.00 & 2.00 & -0.13 & 1.27 & 1.61 & 8 \\
\hline & $\underset{\mathrm{U}}{\mathrm{PEOU}+\mathrm{DM}}$ & -2.00 & 2.00 & 0.18 & 1.16 & 1.34 & 40 \\
\hline \multirow[t]{3}{*}{7} & PEOU_DM & -3.00 & 3.00 & -0.69 & 1.69 & 2.84 & 35 \\
\hline & PEOU_U & -3.00 & 2.00 & -0.71 & 1.67 & 2.78 & 7 \\
\hline & $\begin{array}{c}\text { PEOU_DM_ } \\
\mathrm{U}\end{array}$ & -3.00 & 3.00 & -0.75 & 1.68 & 2.83 & 42 \\
\hline
\end{tabular}


E-business or E-commerce are indicative of technology use (Issa et al. 2003). Companies that utilize ICT for regular business practices are more inclined to be accepting of new ICT and therefore more likely to use/adopt ICT. Table 11 shows the level of e-business use among the respondents' companies. The response mean values for the Decision Makers group were relatively high indicating that they participated more than average in the use of ICT for business functions. This factor emphasizes that those who already use ICT are more inclined to accept new ICT and use it. The mean values of the Users group indicated less use of ICT to conduct business practices and that only higher-level employees conducted business functions for these companies. Even so, the mean values for all categories were close to or above 1.0 indicating highly positive use of EBiz.

Table 11: E-Biz Statistics for Decision Makers, Users, and Combined groups.

\begin{tabular}{|c|c|c|c|c|c|c|c|c|}
\hline \# & Field & Variable & Min. & Max. & Mean & Std. Dev. & Var. & Count \\
\hline \multirow[t]{3}{*}{1} & Accounting Purposes & E-Biz_DM & -1.00 & 3.00 & 1.52 & 1.30 & 1.68 & 63 \\
\hline & & E-Biz_U & -1.00 & 3.00 & 0.62 & 1.08 & 1.16 & 13 \\
\hline & & $\begin{array}{l}\text { E- } \\
\text { Biz_DM_U }\end{array}$ & -1.00 & 3.00 & 1.37 & 1.31 & 1.71 & 76 \\
\hline \multirow[t]{3}{*}{2} & Procurement Purposes & E-Biz_DM & -3.00 & 3.00 & 1.43 & 1.28 & 1.64 & 63 \\
\hline & & E-Biz_U & -1.00 & 3.00 & 0.77 & 1.05 & 1.10 & 13 \\
\hline & & $\begin{array}{l}\text { E- } \\
\text { Biz_DM_U }\end{array}$ & -3.00 & 3.00 & 1.32 & 1.27 & 1.61 & 76 \\
\hline \multirow[t]{3}{*}{3} & $\begin{array}{l}\text { Project Management / Document } \\
\text { Management }\end{array}$ & E-Biz_DM & -1.00 & 3.00 & 2.13 & 1.03 & 1.06 & 63 \\
\hline & & E-Biz_U & -1.00 & 3.00 & 1.31 & 0.91 & 0.83 & 13 \\
\hline & & $\begin{array}{l}\text { E- } \\
\text { Biz_DM_U }\end{array}$ & -1.00 & 3.00 & 1.99 & 1.06 & 1.12 & 76 \\
\hline \multirow[t]{3}{*}{4} & $\begin{array}{l}\text { Billings, Invoices, Payments, Deposit } \\
\text { and Receipts }\end{array}$ & ${ }^{S}$ E-Biz_DM & -1.00 & 3.00 & 1.70 & 1.16 & 1.35 & 63 \\
\hline & & E-Biz_U & -1.00 & 2.00 & 0.69 & 0.99 & 0.98 & 13 \\
\hline & & E-Biz_DM_U & -1.00 & 3.00 & 1.53 & 1.20 & 1.43 & 76 \\
\hline \multirow[t]{3}{*}{5} & $\begin{array}{l}\text { Project Collaboration } \\
\text { Stakeholders }\end{array}$ & E-Biz_DM & -2.00 & 3.00 & 1.37 & 1.38 & 1.91 & 63 \\
\hline & & E-Biz_U & -1.00 & 3.00 & 1.15 & 1.10 & 1.21 & 13 \\
\hline & & E-Biz_DM_U & -2.00 & 3.00 & 1.33 & 1.34 & 1.80 & 76 \\
\hline \multirow[t]{3}{*}{6} & Virtual Depository for Contract Files & E-Biz_DM & -1.00 & 3.00 & 1.68 & 1.28 & 1.65 & 63 \\
\hline & & E-Biz_U & -1.00 & 3.00 & 0.92 & 1.14 & 1.30 & 13 \\
\hline & & $\begin{array}{l}\text { E- } \\
\text { Biz_DM_U }\end{array}$ & -1.00 & 3.00 & 1.55 & 1.29 & 1.67 & 76 \\
\hline \multirow[t]{3}{*}{7} & All Business-Related Functions & E-Biz_DM & -2.00 & 3.00 & 1.37 & 1.26 & 1.60 & 63 \\
\hline & & E-Biz_U & -1.00 & 3.00 & 1.08 & 0.92 & 0.84 & 13 \\
\hline & & E-Biz_DM_U & -2.00 & 3.00 & 1.32 & 1.22 & 1.48 & 76 \\
\hline
\end{tabular}

Table 12 shows the results for compatibility. Respondents seem to be relatively neutral in the adoption or use of new ICT if it meets their needs but is not compatible with subcontractors/trades or suppliers or vendors. Combining the data in Table 12 under Comp_DM_U shows that all the respondents had little consideration for compatibility in considering new tools. 
Table 12: Compatibility Statistics for Decision Makers, Users, and Combined groups.

\begin{tabular}{|c|l|c|l|l|l|l|l|}
\hline$\#$ & \multicolumn{1}{|c|}{ Variables } & Min. & Max. & Mean & Std. Dev. & Var. & Count \\
\hline $1 *-1$ & Comp_DM & -3.00 & 3.00 & -0.44 & 1.81 & 3.26 & 63 \\
\hline $1 *-1$ & Comp_U & -3.00 & 3.00 & -0.46 & 1.55 & 2.40 & 13 \\
\hline $1 *-1$ & Comp_DM_U & -3.00 & 3.00 & -0.45 & 1.77 & 3.12 & 76 \\
\hline $2 *-1$ & Comp_DM & -3.00 & 3.00 & 0.05 & 1.63 & 2.65 & 63 \\
\hline $2 *-1$ & Comp_U & -3.00 & 3.00 & 0.23 & 1.80 & 3.25 & 13 \\
\hline 2 & Comp_DM_U & -3.00 & 3.00 & 0.08 & 1.66 & 2.76 & 76 \\
\hline 3 & Comp_DM & -3.00 & 3.00 & 1.08 & 1.36 & 1.85 & 63 \\
\hline 3 & Comp_U & -2.00 & 3.00 & 0.92 & 1.38 & 1.92 & 13 \\
\hline $3 *-1$ & Comp_DM_U & -3.00 & 3.00 & 1.05 & 1.37 & 1.87 & 76 \\
\hline 4 & Comp_DM & -3.00 & 3.00 & -0.41 & 1.36 & 1.86 & 63 \\
\hline 4 & Comp_U & -2.00 & 2.00 & 0.15 & 1.35 & 1.82 & 13 \\
\hline 4 & Comp_DM_U & -3.00 & 3.00 & -0.32 & 1.38 & 1.90 & 76 \\
\hline
\end{tabular}

Quality of output $(Q O P)$ of the ICT scored in the middle of the ranking in the "Rank" question. The $Q O P$ question indicated (Table 13) that $Q O P$ is somewhat Quality neutral in the consideration of new ICT. The $Q O P$ could be considered part of usefulness. However, the respondents did not seem to consider this part of PU. In question "QOP4_DM_U” usefulness was added to the quality of output and the mean increased. Even so, the re-analysis of these questions yielded a neutral result and matches the general perception of the industry as tending to be reluctant to adopt new methods unless they are extensively proven.

Table 13: QOP 1-2_DM and QOP 3-4_DM_U Statistics.

\begin{tabular}{lllllll}
\hline$\#$ & Minimum & Maximum & Mean & Std. Deviation & Variance & Count \\
\hline 1 & -3.00 & 3.00 & 0.25 & 1.65 & 2.73 & 63 \\
2 & -3.00 & 3.00 & -0.06 & 1.59 & 2.54 & 63 \\
3 & -3.00 & 3.00 & 0.41 & 1.49 & 2.22 & 76 \\
4 & -3.00 & 3.00 & 0.09 & 1.58 & 2.50 & 76 \\
\hline
\end{tabular}

Table 14 shows that the US construction industry has some, but very little influence on the adoption and use of ICT in a specific firm. Construction companies might take into consideration what technologies were being used in the US construction industry, but it seems that the technological solutions that they adopted were based on company or even project specific needs. The respondents indicated (Table 15) that their companies' corporate cultures were relatively good. The mean values showed a moderate level of a culture of innovation, indicating that the firms tended to support new ICT and were more receptive to looking for new ICT solutions.

Table 14: Industry_DM Statistics.

\begin{tabular}{llcccccc}
\hline$\#$ & & Min. & Max. & Mean & Std. Dev. & Variance & Count \\
\hline 1 & Industry_DM & -3.00 & 2.00 & -0.62 & 1.41 & 1.98 & 63 \\
& Industry_U & -3.00 & 2.00 & -0.23 & 1.48 & 2.18 & 13 \\
& Industry_DM_U & -3.00 & 2.00 & -0.55 & 1.43 & 2.04 & 76 \\
2 & Industry_DM & -3.00 & 3.00 & -0.52 & 1.63 & 2.66 & 63 \\
& Industry_U & -2.00 & 2.00 & -0.08 & 1.44 & 2.07 & 13 \\
& Industry_DM_U & -3.00 & 3.00 & -0.45 & 1.61 & 2.59 & 76 \\
$3 *$-1 & Industry_DM & -3.00 & 3.00 & 0.54 & 1.31 & 1.71 & 63 \\
& Industry_U & -3.00 & 2.00 & 0.31 & 1.64 & 2.67 & 13 \\
& Industry_DM_U & -3.00 & 3.00 & -0.50 & 1.37 & 1.88 & 76 \\
4 & Industry_DM & -3.00 & 3.00 & 0.40 & 1.50 & 2.24 & 63 \\
& Industry_U & -2.00 & 2.00 & 1.08 & 1.07 & 1.15 & 13 \\
& Industry_DM_U & -3.00 & 3.00 & 0.51 & 1.46 & 2.12 & 76 \\
\hline
\end{tabular}




\begin{tabular}{|c|c|c|c|c|c|c|c|}
\hline \# & Field & Min. & Max. & Mean & Std. Dev. & Var. & Count \\
\hline 1 & Take Suggestions from Employees on New Computer Tech. & -1.00 & 3.00 & 1.83 & 1.02 & 1.04 & 76 \\
\hline 2 & Upgrade Current Computer Tech. & -2.00 & 3.00 & 1.63 & 1.13 & 1.29 & 76 \\
\hline 3 & Lag Behind the Rest of Their Market in New Computer Tech. & -3.00 & 3.00 & 0.43 & 1.52 & 2.32 & 76 \\
\hline 4 & Lead Their Construction Market in New Computer Tech. & -3.00 & 3.00 & 0.41 & 1.61 & 2.58 & 76 \\
\hline 5 & Consider State-of-the-art Computer Tech. & -2.00 & 3.00 & 1.00 & 1.30 & 1.68 & 76 \\
\hline
\end{tabular}

\subsection{Regression Analysis}

Several regression analyses were conducted of the variables to determine a best fit regression model. The best results from the models are shown in Tables 16 through 19. In each of the regression analyses, the variable actual use sum was entered as the response variable (the dependent variable). Data from the continuous variables were entered into Minitab (Minitab 17 2010) statistical software as modified in the data manipulation section. A stepwise regression with backward elimination was performed for the purpose of this exploratory, predictive research to determine what variables were significant in the model and to find a reduced model that best explains the data (Wang and Chen 2016). In the regression models in Tables 16 and 17 the data from the combined questions of both groups Decision Makers and Users was used for the analysis. A 95 percent confidence level was chosen based on the data collection from a survey. The parameters of the stepwise regression were set to run a backwards elimination process removing all variables with $\alpha<0.05$. PU_Rank_DM_U*-1 and PEOU Rank_DM_U* - 1 were combined in the model along with PU_DM_U_Sum_-PU4 and PEOU_DM_U_Sum based on the relationship established by Davis $(1986,1989)$ in the original TAM model between PU and PEOU. The first regression results are shown in Table 16.

Table 16: Regression model summary with Annual volume for Decision Makers and Users.

\section{Model Summary}

\begin{tabular}{llll}
\hline S & R-sq & R-sq(adj) & R-sq(pred) \\
\hline 5.91150 & $58.40 \%$ & $52.72 \%$ & $43.28 \%$
\end{tabular}

\section{Coefficients}

\begin{tabular}{|c|c|c|c|c|c|c|}
\hline Term & & Coef. & SE Coef. & T-Value & P-Value & VIF \\
\hline Constant & & 8.66 & 2.90 & 2.99 & 0.004 & \\
\hline Influence2_DM_U & & 1.829 & 0.686 & 2.66 & 0.010 & 1.36 \\
\hline \multicolumn{7}{|l|}{ Small_DM_U } \\
\hline Yes & & -6.88 & 1.75 & -3.94 & 0.000 & 1.29 \\
\hline PU_DM_U_Sum_-PU4 & & 0.640 & 0.243 & 2.64 & 0.010 & 1.37 \\
\hline QOP_DM_U_Sum & & -0.734 & 0.299 & -2.46 & 0.017 & 1.40 \\
\hline Cult_DM_U_Sum & & 0.503 & 0.165 & 5.05 & 0.003 & 1.34 \\
\hline PEOU_DM_U+Ind2_DM_U+QOP2_DM_U & & -1.498 & 0.620 & -2.41 & 0.019 & 21.11 \\
\hline Industry2_DM_U & & 1.327 & 0.512 & 2.59 & 0.012 & 1.48 \\
\hline $\begin{array}{l}\text { PU_DM_U_Sum_-PU4 } \\
\text { PEOU_DM_U+Ind2_DM_U+QOP2_DM_U }\end{array}$ & & * 1.1401 & 0.0505 & 2.77 & 0.007 & 21.10 \\
\hline Annual Volume_DM_U/1billion & & 1.146 & 0.352 & 3.26 & 0.002 & 1.48 \\
\hline \multicolumn{7}{|l|}{ Regression Equation } \\
\hline Actual Use count_DM_U & $=$ & \multicolumn{5}{|c|}{$\begin{array}{l}\text { 8.66 + 1.829 Influence2_DM_U + 0.640 PU_DM_U_Sum_-PU4 } \\
\text { - 0.734 QOP_DM_U_Sum + 0.503 Cult_DM_U_Sum } \\
\text { - } 1.498 \text { PEOU_DM_U+Ind2_DM_U+QOP2_DM_U } \\
\text { + 1.327 Industry2_DM_U+0.1401 PU_DM_U_Sum_- } \\
\text { - PU4*PEOU_DM_U+Ind2_DM_U+QOP2_DM_U } \\
\text { + 1.146 Annual Volume_DM_U/1billion }\end{array}$} \\
\hline Actual Use count_DM_U & $=$ & \multicolumn{5}{|c|}{$\begin{array}{l}\text { 1.78 + 1.829 Influence2_DM_U + 0.640 PU_DM_U_Sum_-PU4 } \\
\text { - 0.734 QOP_DM_U_Sum + 0.503 Cult_DM_U_Sum } \\
\text { - 1.498 PEOU_DM_U+Ind2_DM_U+QOP2_DM_U } \\
\text { + 1.327 Industry2_DM_U+0.1401 PU_DM_U_Sum_- } \\
\text { - PU4*PEOU_DM_U+Ind2_DM_U+QOP2_DM_U } \\
\text { + 1.146 Annual Volume_DM_U/1billion }\end{array}$} \\
\hline
\end{tabular}


The original regression model was run with several of the categorical variables included from the survey data collection. The predictability of the model, for each iteration of the regression analysis, was not improved by adding them. The annual construction volume/1 billion variable was added to the regression model in Table 16 and resulted in an increase in the predictability of the model and was significant. It stands to reason that higher annual construction volumes would lead to more overall technology use, because these respondents most likely were involved in larger and more complex construction projects. Similarly, the larger the company the more likely they are to be able to afford multiple technologies and the ability to support them, however, this was not the case for the larger residential US construction companies. Larger companies would also need more IT staff to service and support ICT use. Adding this variable to the model added no insight to the predictability of ICT use. Companies that have IT staff are more likely to adopt and use computer ICT on a greater scale. The $\mathrm{R}^{2}$ value for the combined data regression model not including the annual sales volume variable was $50.11 \%$ (Table 17). This is within the realm of predictability level of the TAM of 40-50\% user acceptance of technology (Davis 1986, 1989 and Park 2009). Adding in the annual sales volume to the regression model (Table 16) increased the $\mathrm{R}^{2}$ to $58.40 \%$, thus increasing the predictability of the model.

Table 17: Regression analysis of combined groups.

Model Summary

\begin{tabular}{llll}
\hline S & R-sq & R-sq(adj) & R-sq(pred) \\
\hline 6.37764 & $50.11 \%$ & $44.97 \%$ & $36.02 \%$
\end{tabular}

\section{Coefficients}

\begin{tabular}{|c|c|c|c|c|c|}
\hline Term & Coef. & SE Coef & T-Value & P-Value & VIF \\
\hline Constant & 11.88 & 2.94 & 4.04 & 0.000 & \\
\hline \multicolumn{6}{|l|}{ Small_DM_U } \\
\hline Yes & -6.89 & 1.80 & -3.84 & 0.000 & 1.17 \\
\hline PU_DM_U_Sum_-PU4 & 0.679 & 0.261 & 2.60 & 0.011 & 1.36 \\
\hline QOP_DM_U_Sum & -0.765 & 0.319 & -2.40 & 0.019 & 1.36 \\
\hline Cult_DM_U_Sum & 0.689 & 0.169 & 4.09 & 0.000 & 1.20 \\
\hline PEOU_DM_U+Ind2_DM_U+QOP2_DM_U & -1.554 & 0.669 & -2.32 & 0.023 & 21.08 \\
\hline Industry2_DM_U & 1.685 & 0.540 & 3.12 & 0.003 & 1.41 \\
\hline PU_DM_U_Sum_-PU4 & * 0.1364 & 0.0544 & 2.51 & 0.015 & 21.02 \\
\hline
\end{tabular}

\section{Regression Equation}

\begin{tabular}{|c|c|c|c|}
\hline \multicolumn{4}{|c|}{ Small_DM_U } \\
\hline No & Actual Use count_DM_U & & $\begin{array}{l}11.88+0.679 \text { PU_DM_U_Sum_-PU4 - } 0.765 \text { QOP_DM_U_Sum } \\
\text { + } 0.689 \text { Cult_DM_U_Sum-1.554 PEOU_DM_U+Ind2_DM_U } \\
\text { +QOP2_DM_U+1.685 Industry2_DM_U } \\
\text { + } 0.1364 \text { PU_DM_U_Sum_- } \\
\text { - PU4*PEOU_DM_U+Ind2_DM_U+QOP2_DM_U }\end{array}$ \\
\hline Yes & Actual Use count_DM_U & $=$ & $\begin{array}{l}4.99+0.679 \text { PU_DM_U_Sum_-PU4 - } 0.765 \text { QOP_DM_U_Sum } \\
\quad+0.689 \text { Cult_DM_U_Sum } \\
\quad \text { - } 1.554 \text { PEOU_DM_U+Ind2_DM_U+QOP2_DM_U } \\
\quad+1.685 \text { Industry2_DM_U } \\
\quad \text { PU4*PEOU_DM_U+Ind2_DM_U+QOP2_DM_U }\end{array}$ \\
\hline
\end{tabular}

PU, Cult, Industry2, and combined PU and PEOU all have positive influence on actual use of ICT as indicated by positive coefficients and significant p-values in Tables 16 through 19. PEOU was shown to be significant in Tables 16, 17 and 19 and not in Table 18. QOP was similarly shown to be significant in Tables 16, 17 and 19 but not in Table 18. However, as shown in Tables $16-19$, both have a negative coefficient indicating that respondents were willing to give up ease of use and quality of output for other attributes that were deemed more important. The Combination of PU and PEOU was also shown to be significant in Tables 16, 17 and 19 but not in Table 18. This indicates that the Decision Makers group did not find ease of use necessary in selecting ICT. Small business was also an indicator of adverse use of ICT which made sense intuitively. Although PEOU was shown to have a 
negative correlation to actual use in the models (Tables 16 and 17), the combination of PU and PEOU had a positive correlation in these models. Similar to the TAM, PEOU supported PU and increased actual use.

Table 18: Regression model summary for “Decision Makers” group only.

\begin{tabular}{|c|c|c|c|c|c|c|c|c|}
\hline \multicolumn{5}{|c|}{ Model Summary } & & & & \\
\hline $\mathrm{S}$ & R-sq & R-sq(adj) & \multicolumn{2}{|c|}{ R-sq(pred) } & & & & \\
\hline 5.88026 & $58.14 \%$ & $50.09 \%$ & \multicolumn{2}{|c|}{$36.56 \%$} & & & & \\
\hline \multicolumn{9}{|c|}{ Coefficients } \\
\hline \multicolumn{3}{|c|}{ Term } & \multicolumn{2}{|c|}{ Coef } & SE Coef & T-Value & P-Value & VIF \\
\hline \multicolumn{3}{|l|}{ Constant } & \multicolumn{2}{|c|}{-1.91} & 4.80 & -0.40 & 0.693 & \\
\hline \multicolumn{3}{|c|}{ Cost_Rank_DM*-1 } & \multicolumn{2}{|c|}{-1.031} & 0.494 & -2.09 & 0.042 & 1.29 \\
\hline \multicolumn{3}{|c|}{ Comp_Rank_DM*-1 } & \multicolumn{2}{|c|}{-0.870} & 0.496 & -1.75 & 0.085 & 1.19 \\
\hline \multicolumn{3}{|c|}{ Influence2_DM } & \multicolumn{2}{|c|}{1.466} & 0.794 & 1.84 & 0.071 & 1.35 \\
\hline \multicolumn{3}{|c|}{ PU_DM_Sum_-PU4 } & \multicolumn{2}{|c|}{0.674} & 0.269 & 2.51 & 0.015 & 1.43 \\
\hline \multicolumn{3}{|c|}{ E-Biz_DM_Sum } & \multicolumn{2}{|c|}{0.320} & 0.121 & 2.65 & 0.011 & 1.22 \\
\hline \multicolumn{3}{|c|}{ QOP_DM_Sum } & \multicolumn{2}{|c|}{-0.341} & 0.195 & -1.75 & 0.087 & 1.85 \\
\hline \multicolumn{3}{|c|}{ Cost1-3_Sum } & \multicolumn{2}{|c|}{0.745} & 0.339 & 2.19 & 0.033 & 1.96 \\
\hline \multicolumn{3}{|c|}{ Cost 4} & \multicolumn{2}{|c|}{1.716} & 0.547 & 3.14 & 0.003 & 1.72 \\
\hline \multicolumn{3}{|c|}{ Industry2_DM } & \multicolumn{2}{|c|}{1.678} & 0.546 & 3.08 & 0.003 & 1.44 \\
\hline \multicolumn{9}{|c|}{ Small_DM } \\
\hline Yes & & & \multicolumn{2}{|c|}{-5.23} & 1.98 & -2.64 & 0.011 & 1.51 \\
\hline \multicolumn{9}{|c|}{ Regression Equation } \\
\hline No & \multicolumn{4}{|c|}{ Actual Use count_DM } & \multicolumn{4}{|c|}{$\begin{array}{l}\text {-1.91 - 1.031 Cost_Rank_DM*-1 - 0.870 Comp_Rank_DM*-1 } \\
\quad+1.466 \text { Influence2_DM + 0.674 PU_DM_Sum_-PU4 } \\
\quad+0.320 \text { E-Biz_DM_Sum - 0.341 QOP_DM_Sum + 0.745 Cost1 } \\
\quad \text { - 3_Sum + 1.716 Cost } 4+1.678 \text { Industry2_DM }\end{array}$} \\
\hline Yes & \multicolumn{4}{|c|}{ Actual Use count_DM } & \multicolumn{4}{|c|}{$\begin{array}{l}\text {-7.14 - } 1.031 \text { Cost_Rank_DM*-1 - 0.870 Comp_Rank_DM*-1 } \\
\quad+1.466 \text { Influence2_DM + 0.674 PU_DM_Sum_-PU4 } \\
\quad+0.320 \text { E-Biz_DM_Sum - 0.341 QOP_DM_Sum + 0.745 Cost } 1 \\
\text { - 3_Sum + 1.716 Cost } 4 \text { + 1.678 Industry2_DM }\end{array}$} \\
\hline
\end{tabular}

Several regression models were run to develop the final regression models. Each of these different combinations produced changes in predictability based on the different combinations of variables and manipulated data. The resulting models shown in Tables 16-19 were the best fit scenarios for the groups tested, after utilizing many different combinations of variables.

These variables were added and subtracted from the regression model to find the best fit predictors of ICT use. The resulting regression models represented the highest $\mathrm{R}^{2}$ values for each of the scenarios. The modified annual construction volume was included in the regression analysis shown in Table 16 but not in the regression models in Tables 17-19. The analysis in Table 18 was similar to Table 17, with the data used selected from the Decision Makers group by removing all respondents who considered themselves not informed of the decision or neither informed nor consulted. The $\mathrm{R}^{2}$ value increased, increasing the. predictability of the model. Cost variables were added to the model in Table 18 and the results for Cost1-3 were combined and the data for Cost 4, Cost 5 and Cost 6 were left independent based on the Cronbach $\alpha$ score for the set.

As shown in Table 18, PU, Influence2, E-biz, Cost1-3_Sum and Cost4 became significant and positive. On the other hand: Cost_Rank_DM*-1, Comp_Rank_DM*-1, and QOP_DM_Sum were shown to be negative predictors of actual use/adoption. This may indicate that the Decision Makers group saw these attributes as less important than other attributes of ICT when comparing solutions. Cost does not seem to be a factor in the prediction of use as long as other attributes are moderately present in ICT. Cost1-3_Sum and Cost 4 being a positive predictor of use indicates that usefulness outweighs higher cost, as shown in the other models (Table 16 and 17). The positive Influence 2 predictor indicates that Decision Makers pay more attention to industry standards than PEOU. The negative Comp variable predictor could indicate that companies look inward toward technological solutions rather 
than what would work for companies they work with. QOP_DM_Sum being a negative predictor of use indicates that Decision Makers are less inclined to want high quality output and are more focused on the usefulness of the output.

Table 19: Regression with subtracted out actual decision makers.

\begin{tabular}{|c|c|c|c|c|c|c|c|c|c|c|}
\hline \multicolumn{5}{|c|}{ Model Summary } & & & & & & \\
\hline $\mathrm{S}$ & R-sq & R-sq(adj) & \multicolumn{2}{|c|}{ R-sq(pred) } & & & & & & \\
\hline 6.37559 & $52.83 \%$ & $47.14 \%$ & \multicolumn{2}{|c|}{$37.20 \%$} & & & & & & \\
\hline \multicolumn{11}{|c|}{ Coefficients } \\
\hline \multicolumn{5}{|c|}{ Term } & & Coef & SE Coef & T-Value & P-Value & VIF \\
\hline \multicolumn{5}{|l|}{ Constant } & & 10.55 & 3.28 & 3.22 & 0.002 & \\
\hline \multicolumn{5}{|c|}{ PU_DM_U_Sum_-PU4 } & & 0.770 & 0.293 & 2.62 & 0.011 & 1.32 \\
\hline \multicolumn{5}{|c|}{ QOP_DM_U_Sum } & & -0.644 & 0.341 & -1.89 & 0.063 & 1.46 \\
\hline \multicolumn{5}{|c|}{ Cult_DM_U_Sum } & & 0.757 & 0.176 & 4.29 & 0.000 & 1.18 \\
\hline \multicolumn{5}{|c|}{ PEOU_DM_U+Ind2_DM_U+QOP2_DM_U } & & -1.297 & 0.790 & -1.64 & 0.106 & 25.38 \\
\hline \multicolumn{5}{|c|}{ Industry2_DM_U } & & 1.308 & 0.610 & 2.15 & 0.036 & 1.57 \\
\hline \multicolumn{11}{|c|}{ Small_DM_U } \\
\hline \multicolumn{5}{|c|}{ Yes } & & -8.30 & 2.01 & -4.13 & 0.000 & 1.10 \\
\hline \multicolumn{6}{|c|}{$\begin{array}{l}\text { PU_DM_U_Sum_- } \\
\text { PU4*PEOU_DM_U+Ind2_DM_U+QOP2_DM_U }\end{array}$} & 0.1079 & 0.0634 & 1.70 & 0.094 & 25.45 \\
\hline \multicolumn{11}{|c|}{ Regression Equation } \\
\hline \multicolumn{5}{|c|}{ No $\quad$ Ac } & \multicolumn{6}{|c|}{$\begin{array}{l}\text { 10.55+ 0.770 PU_DM_U_Sum_-PU4- 0.644 QOP_DM_U_Sum } \\
\text { + 0.757 Cult_DM_U_Sum } \\
\text { - } 1.297 \text { PEOU_DM_U+Ind2_DM_U+QOP2_DM_U } \\
\text { + } 1.308 \text { Industry2_DM_U + 0.1079 PU_DM_U_Sum_ } \\
\text { - PU4*PEOU_DM_U+Ind2_DM_U+QOP2_DM_U }\end{array}$} \\
\hline Yes & \multicolumn{4}{|c|}{ Actual Use count_DM_U } & \multicolumn{6}{|c|}{$\begin{array}{l}\text { 2.25 + 0.770 PU_DM_U_Sum_-PU4 - 0.644 QOP_DM_U_Sum } \\
\text { + 0.757 Cult_DM_U_Sum } \\
\text { - } 1.297 \text { PEOU_DM_U+Ind2_DM_U+QOP2_DM_U } \\
\text { + 1.308 Industry2_DM_U+0.1079 PU_DM_U_Sum_- } \\
\text { - PU4*PEOU_DM_U+Ind2_DM_U+QOP2_DM_U }\end{array}$} \\
\hline
\end{tabular}

Some independent variables were removed from the model by the backwards elimination process. The results indicated that removing the User group decreased the significance of those variables. Specifically, the PU_Rank_DM*-1 * PEOU Rank_DM*-1 and PU_DM_Sum_-PU4 *PEOU_DM_Sum+Ind2_QOP2_QOP4 variables that were combined to determine whether their combined data added to the predictability of the model were removed through this elimination process. This indicates that the Decision Makers group does not place high importance on PEOU and therefore the variable lost significance in this model. Even so, PEOU must have added some predictability to the model and might be significant at a lower confidence level because of the low number of Users group respondents removed from the model. Small companies are still predicted to have lower overall ICT use/adoption in this model (Table 18) as it did in the previous models.

The actual decision makers were eliminated from the model for the final regression analysis in Table 19. Respondents who had indicated that they were the actual decision maker in adopting new ICT were removed and the regression was re-run. The results, as shown in Table 19, yielded the same predictor variables as those shown in Table 17. The $\mathrm{R}^{2}$ value increased in this model indicating that the model is a slightly better predictor of actual use than the first regression model in Table 16, leading to the conclusion that actual decision makers bring down the predictability of the model. Another conclusion is that cost does play a role in the predictability of the model, since cost was not included (other than in the ranking) in the Tables 16 and 18 models. E-biz was only a factor in the Table 18 model due to the actual decision makers being more likely to engage in it. 


\section{CONCLUSIONS}

Predictors of actual use in the US construction industry can be attributed to PU, which seem to be supported by PEOU and industry influence, and how innovative and supportive the culture of a construction company is regarding the use and/or adoption of new ICT. The extended TAM developed in this study, while not necessarily possessing the ability to predict actual use better than any of the TAMs previously discussed in the literature review, does indicate that the US construction industry is in line with other US industries and the attributes associated with use and adoption of ICT.

The $\mathrm{H} 1_{\mathrm{o}}$ and $\mathrm{H} 2$ o hypotheses were intended to test questions Q1 and Q2 respectively and were both rejected at the 95\% confidence level. The original TAM explains actual use of ICT in the US construction industry as posed in research question Q1. PU is a significant predictor of ICT use and PEOU supports PU in the combined regression model. PU explains more of the use of ICT in the US construction industry then PEOU. PEOU does support PU but without further research it is unknown to what extent.

The $\mathrm{H} 3_{\mathrm{o}}$ through $\mathrm{H} 8_{\mathrm{o}}$ hypotheses were intended to verify research question $\mathrm{Q} 3 . \mathrm{H} 3_{\mathrm{o}}, \mathrm{H} 4_{\mathrm{o}}, \mathrm{H} 5_{\mathrm{o}}$ and $\mathrm{H} 8_{\mathrm{o}}$ were accepted at the $95 \%$ confidence level, while both $\mathrm{H} 5_{\mathrm{o}}$ and $\mathrm{H} 8_{\mathrm{o}}$ were rejected at the 95 percent confidence level. Question Q3 was intended to examine what other attributes might be of interest to US construction firms when selecting new ICT. Industry Influence and Culture were found to be predictors of ICT use in the US construction industry.

Figure 1 shows the results of this study, which are: PU, Cult(ure), and Industry Influence are all predictors of intention to use ICT in the US construction industry. Furthermore, PU is supported by PEOU based on the combination of the PU and PEOU variables in the regression models. Cult and Industry Influence also support PEOU based on the relationships established in the variables. PEOU could not be shown to influence utilization directly based on the negative relationship found in the regression models. Further research is needed to determine what direct effect PEOU has on actual use of ICT in the US construction industry.

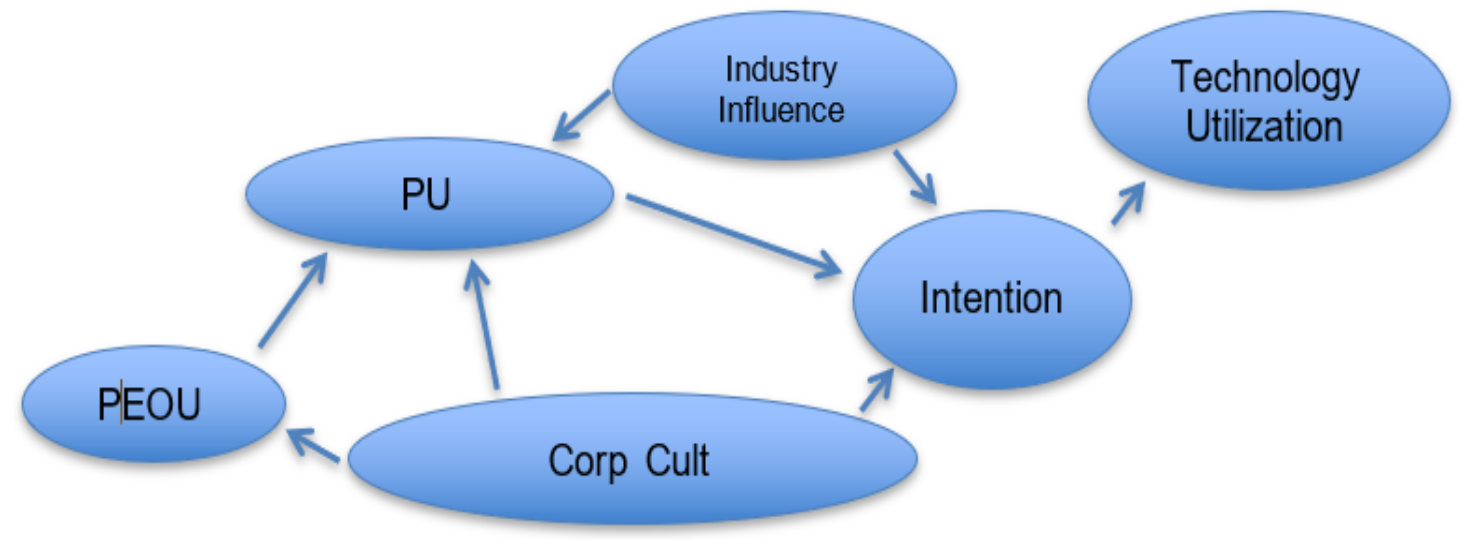

Fig. 1: Model of ICT acceptance in the construction industry

The limitations of this study include the small sample size, the availability for analysis purposes of only four of the seven PEOU questions responses due to a survey instrument error, the lack of regional and job responsibility diversity among respondents, the use of the word serious in describing cost implications for Cost4-6 which might have caused a discrepancy in its interpretation and the response. PU4 seemed to be misconstrued by the respondents and adding in a monetary value to the cost of ICT and including an ROI cost-benefit analysis would also add insight to the study. Trialability (Rogers 1995) was not tested and defining usefulness to construction firms may have added further insight. Other limiting major factors, also found in other similar US construction industry studies, include low response rate, and length of time to receive responses.

Furthermore, a more careful approach should be taken in asking probing questions related to ease of use. Tradeoffs in functionality are self-serving and respondents should be asked more precise questions regarding functionality's relationship to use and adoption. Additional studies indicating what construction firms actually find useful in construction ICT; what makes the construction industry so ICT averse; impact of trialability on ICT adoption; the role of new standards on shaping ICT use and adoption in the built environment; and whether the next generation of contractors will have this same attitude should be explored in the future. 
Ultimately, ICT will be infused into a firm through adaptation. Employees must have "buy in" and acceptance of this culture of innovation to fully realize the potential impact that ICT has on the business model. To create this "buy in" companies must show dedication to the ICT and to the employees that use it. Furthermore, employees must feel that they are part of the process by feeling that they have decision making ability and have some control over how their jobs get done.

\section{REFERENCES}

Ajzen, I., and Fishbein, M. (1980). Understanding attitudes and predicting social behavior, Prentice-Hall, Englewood Cliffs, NJ.

Andriole, S. J. (2014). Ready Technology. Com. of the ACM, 57(2), 40-42. doi:10.1145/2556941

Blayse, A. M., and Manley, K. (2004). Key influences on construction innovation. Construction innovation, 4(3), 143-154.

Brown, S. A., Dennis, A. R., and Venkatesh, V. (2010). "Predicting collaboration technology use: integrating technology adoption and collaboration research." J. MIS, 27(2), 9-53.

Buchanan, T., Sainter, P., and Saunders, G. (2013). "Factors affecting faculty use of learning technologies: implications for models of technology adoption." J. MIS, 25 (1), 1-11.

Chou, Y., Hao-Chun Chuang, H., and Shao, B. B. M. (2014). The impacts of information technology on total factor productivity: A look at externalities and innovations. Int. J. of Production Economics, 158, 290-299. doi:10.1016/j.ijpe.2014.08.003

Costin, A. M., Teizer, J., and Schoner, B. (2015). RFID and BIM-enabled worker location tracking to support realtime building protocol and data visualization. ITcon, 20(29), 495-517.

Davis, F. D. (1989). "Perceived Usefulness, Perceived Ease of Use, and User Acceptance of Information Technology." MIS Quarterly, 13(3), 319-340.

Davis, F. D., Bagozzi, R. P., and Warshaw, P. R. (1989). User Acceptance of Computer Technology: A Comparison of Two Theoretical Models. Management Science, 35(8), 982-1003. Retrieved from http://www.jstor.org/stable/2632151

Denning, P. J. (2014). 'Surfing Toward the Future'. Com. of the ACM, 57(3), 26-29. doi:10.1145/2566967

Fayad, R. (2006). Extension of the technology acceptance model in electronic commerce. Thesis Utah State University.

Gambatese, J., and Hallowell, M. (2011). "Factors that influence the development and diffusion of technical innovations in the construction industry." Construction Management and Economics, 29(5), 507-517.

Gonzalez, G. C., Sharma, P. N., and Galletta, D. (2012). Factors influencing the planned adoption of continuous monitoring technology. Journal of Information Systems, 26(2), 53-69

Goodrum, P. M., and Haas, C. T. (2004). Long-term impact of equipment technology on labor productivity in the U.S. construction industry at the activity level. Journal of Construction Engineering and Management, 130(1), 124-133. doi:10.1061/(ASCE)0733-9364(2004)130:1(124)

Grau, D., Caldas, C. H., Haas, C. T., Goodrum, P. M., and Gong, J. (2009). Assessing the impact of materials tracking technologies on construction craft productivity. Automation in Construction, 18, 903-911. doi:10.1016/j.autcon.2009.04.001

Ismail, A. R. (2012). Understanding the factors that affect the adoption of innovative high-technology brands: The case of apple iPhone in Malaysia. Journal of Global Marketing, 25(4), 226-239.

Issa, R. R. A., Flood, I., and Caglasin, G. (2003). A survey of e-business implementation in the US construction industry. Journal of Information Technology in Construction, 8, 15-28.

Kereri, J.O. and Adamtey, S. (2019), "RFID use in residential/commercial construction industry", Journal of Engineering, Design and Technology, Vol. 17 No. 3, pp. 591-612. https://doi.org/10.1108/JEDT-07-20180118

Kim, S. W., and Narasimhan, R. (2002). Information system utilization in supply chain integration efforts. International Journal of Production Research, 40(18), 4585-4609. 
Lee, Y., Kozar, K., and Larsen, K. (2003). “The Technology Acceptance Model: Past, Present, and Future." Communications of the Association for Information Systems 12(50): 752-780, December 2003.

Lee, S., Yu, J., and Jeong, D. (2015). "BIM Acceptance Model in Construction Organizations.” Journal of Management in Engineering. 31(3): 04014048.

Liu, D., Lu, W., and Niu, Y (2018). "Extended Technology-Acceptance Model to Make Smart Construction Systems Successful.” J. Constr. Eng. Manage., 2018, 144(6): 04018035

Mačiulytė-Šniukienè, A., and Gaile-Sarkane, E. (2014). Impact of information and telecommunication technologies development on labour productivity. Procedia - Social and Behavioral Sciences, 110(2-), 1271-1282. doi:10.1016/j.sbspro.2013.12.974

Malek, M., Sorce, J. and Murcia, J. (2012). Overview of Emerging Technological Innovations in Construction Management. The American Professional Constructor (American Institute of Constructors Journal), (36), Number 4, pp. 5-11.

McKinsey Global Institute (2017). Reinventing Construction: A Route To Higher Productivity, McKinsey \& Co., Boston, MA.

Menon, M. A., and Varghese, S. (2018). Labour Productivity Measurement method using 3D BIM of a Commercial Project. Labour, 5(05).

Minitab 17 Statistical Software (2010). [Computer software]. State College, PA: Minitab, Inc. (www.minitab.com)

Miozzo, M., and Dewick, P. (2004). Innovation in European construction, Edward Elgar, Cheltenham, PA.

Mitropoulos, P and Tatum, C. B. (1999). Technology adoption decisions in construction organizations. J. Constr. Eng. Mgmt., 125(5), 330-338. doi:10.1061/(ASCE)0733-9364(1999)125:5(330)

Nam, C. H., and Tatum, C. B. (1992). "Strategies for technology push: Lessons from construction innovations.” J. Constr. Eng. Mgmt., 10.1061/(ASCE)0733-9364(1992)118:3(507), 508-24.

Ozorhon, B., and Oral, K. (2016). Drivers of Innovation in Construction Projects. J. Constr. Eng. Mgmt., 04016118.

Peansupap, V., and Walker, D. H. (2005). "Factors enabling information and communication technology diffusion and actual implementation in construction organizations". ITcon, 10(14), 193-218.

Rave-Habhab, S. (2011). "Place de la culture d'entreprise dans un processus d'innovation chez les PME de haute technologie: une étude de cas par comparaison inter sites. (French)." Revue Management Et Avenir, (50), 78-104.

Rogers, M. (2006). "Einstein, Albert. Out of My Later Years.(Brief review)." Library Journal, 131(7), 126.1995

Teizer, J., Cheng, T., and Fang, Y. (2013). "Location tracking and data visualization technology to advance construction ironworkers' education and training in safety and productivity." Automation in Construction, 35, 53-68. doi:10.1016/j.autcon.2013.03.004

Tong, C., Wong, A., and Lee, W. (2015). Barriers to Software Adoption. 139 Attitude towards the Brand: Does Advertising Exposure Matter? 179.

Venkatesh, V., and Davis, F. D. (2000). "A Theoretical Extension of the Technology Acceptance Model: Four Longitudinal Field Studies." Management Science, 46(2), 186-204.

Venkatesh, V., Morris, M. G., Davis, F. D., and Davis, G. B. (2003). "User Acceptance of Information Technology: Toward a Unified View." MIS Quarterly, 27(3), 425-478.

Venkatesh, V., Thong, J. Y., and Xu, X. (2012). "Consumer acceptance and use of information technology: extending the unified theory of acceptance and use of technology.” MIS Quarterly, Vol. 36, No. 1, pp. 157178.

Wang, K., and Chen, Z. (2016). "Stepwise regression and all possible subsets regression in education.” Electron. Int. J. Educ. Arts Sci. 2 (1): 60-81.Wang, P., Wu, P., Wang, J., Chi, H. L., and Wang, X. (2018). “A Critical Review of the Use of Virtual Reality in Construction Engineering Education and Training." International journal of environmental research and public health, 15(6), 1204. 
Williams, T., Bernold, L., and Lu, H. (2007). "Adoption patterns of advanced information technologies in the construction industries of the United States and Korea." J. Constr. Eng. Mgmt.,133(10),780-90.

Zhai, D., Goodrum, P. M., Haas, C. T., and Caldas, C. H. (2009). "Relationship between automation and integration of construction information systems and labor productivity." J. Constr. Eng. Mgmt., 135(8), 746-753. doi:10.1061/(ASCE)CO.1943-7862.0000024

Zhu, Y. (2009). "Exploratory Study on Value of Information Systems to Electrical Construction Companies: Resource-Based View." J. of Mgmt. in Eng., 25(2), 50-58. doi:10.1061/(ASCE)0742597X(2009)25:2(50). 